\title{
Tracer tests in karst hydrogeology and speleology
}

\author{
Nico Goldscheider ${ }^{1 *}$, Joe Meiman ${ }^{2}$, Michiel Pronk ${ }^{1}$, Christopher Smart ${ }^{3}$
}

\begin{abstract}
:
Goldscheider N., Meiman J., Pronk M and Smart C. 2008. Tracer tests in karst hydrogeology and speleology. International Journal of Speleology, 37 (1), 27-40. Bologna (Italy). ISSN 0392-6672.

This article presents an introduction to the fundamentals of tracing techniques and their application in cave and karst environments, illustrated by case studies from the Mammoth Cave, USA, and a small experimental site in Switzerland. The properties and limitations of the most important artificial tracers are discussed, and the available methods of tracer injection, sampling, online monitoring and laboratory analysis are presented. Fully quantitative tracer experiments resultin continuous or discrete concentration-time data series, i.e. breakthrough curves, and concomitant discharge data, which make it possible to obtain detailed information about groundwater flow and contaminant transport. Within the frame of speleological investigations, tracer tests can help to resolve the active and often inaccessible part of cave and conduit networks and to obtain indications about the geometry and volume of the conduits. For hydrogeological studies, caves can in turn be used as natural experimental and monitoring sites inside the unsaturated or saturated zone of karst aquifer systems.

Keywords: Tracing techniques, hydrogeology, karst, Mammoth Cave, Switzerland
\end{abstract}

Received 8 August 2007; Revised 14 November 2007; Accepted 20 November 2007

\section{INTRODUCTION}

Tracing techniques can be used in all types of hydrological and hydrogeological environments to obtain information about water movement and contaminant transport (Käss, 1998). However, the methodology of water tracing was initially developed for the investigation of karst aquifers, and is still most widely used in karst, where groundwater trajectories are not immediately apparent. Tracer tests, combined with geological and hydrological observations, are the most powerful method to delineate the catchment areas of karst springs, even in complicated geological and topographic settings (e.g. Goldscheider, 2005). Tracer tests in caves are mostly used to identify active conduit networks, although caves also provide natural experimental and monitoring sites inside the aquifer (Benischke et al., 2007).

1 Centre of Hydrogeology, University of Neuchâtel, Rue Emile-

Argand 11, 2009 Neuchâtel, Switzerland

2 Inventory and Monitoring Program, Southeast Region,

National Park Service, P.O. Box 8, Mammoth Cave, KY 42259,

USA

3 Department of Geography, University of Western Ontario,

London, Ontario N6A 5C2, Canada

* Corresponding author. Phone: +41 32718 2645;

email: nico.goldscheider@unine.ch
Accessible caves only constitute a relatively small proportion of the total conduit network in a karst aquifer (Jeannin et al., 2007). Tracer tests can provide information about the inaccessible parts, mainly in delimiting the active conduits that convey underground water, not only between swallow holes, cave streams and springs, but also between different parts of a cave system. Tracer travel times allow flow velocities to be determined if an appropriate flow distance is known. Tracer data, together with flow measurements, can also be used to estimate conduit cross-sectional areas and volumes, and to resolve conduit networks in more detail (Smart, 1988a). More advanced interpretation techniques allow the quantification of relevant contaminant transport parameters, such as dispersivity, retardation and degradation, as well as the characterisation of conduit-matrix interactions (e.g. Geyer et al., 2007; Massei et al., 2006).

Exploitation of caves as hydrogeological monitoring and experimental sites has become increasingly important. For studies dealing with groundwater vulnerability, contamination and attenuation processes, it is often insufficient to monitor only the input and output, i.e. the land surface and swallow holes on one side, and springs or wells on the other side. Caves offer the opportunity to directly observe what is happening inside the karst aquifer (e.g. Boyer \& Pasquarell, 1999). In particular, caves make it 
possible to characterise flow and transport in the unsaturated zone by injection of tracers at the land surface and sampling drip points and other water inlets inside the cave (e.g. Perrin et al., 2004).

This article presents an overview of the general methodology of water tracing and then presents examples to illustrate some speleological and hydrogeological applications. Here, the term 'tracer' refers to artificial tracers, i.e. substances such as fluorescent dyes that are intentionally released by the investigator in order to label flowing water. Complementary information may be obtained using natural hydrochemical tracers (Hunkeler \& Mudry, 2007) and natural isotopic tracers (Criss et al., 2007), but this is beyond the scope of this paper.

\section{GENERAL TRACER TECHNIQUE}

\section{Types of artificial tracers}

This section and Table 1 provide a brief summary of the most important tracers in hydrogeology. Tracers can be grouped into conservative and nonconservative (or reactive) substances, and into solutes and particles. An extensive description can be found in Käss (1998); Benischke et al. (2007) focus on the use of common tracers in karst hydrogeology.

Conservative tracers are stable in groundwater and show no interaction with aquifer materials. There are no perfectly conservative tracers, although some are nearly so. Conservative tracers exactly mimic water movement; they also represent transport of conservative, aqueous phase contaminants. Nonconservative tracers can be used to simulate the transport and attenuation of contaminants with analogous reactive properties.

Solute tracers are substances that dissolve in water. Particulate tracers include colloidal substances $(<1 \mu \mathrm{m})$ and larger particles that can be used as surrogates for particle-bound chemical contaminants and microbial pathogens. Particulate tracers can experience a wide range of filtration, sedimentation, exclusion or other processes.

The most important solute tracers are fluorescent dyes, i.e. synthetic organic compounds that absorb light at specific wavelengths and emit fluorescence light at longer wavelengths. This optical property results in very low analytical detection limits. For many applications, the green fluorescent dye uranine (sodium fluorescein) is a preferred groundwater tracer, as it is highly soluble, inexpensive, toxicologically safe, and has an extremely low detection limit of $\sim 0.005 \mu \mathrm{g} / \mathrm{L}$. In acid and organic-rich environments, uranine degrades or is difficult to detect, so is not appropriate. Other recommended fluorescent tracers include eosin, certain rhodamines, sodiumnaphthionate and tinopal CBS-X. Most fluorescent dyes are sensitive to light and to strong oxidants (such as may be applied during water treatment). The Chemical Abstracts Service Registry Numbers (CAS RN) in Table 1 allow unambiguous identification (see internet link at the end of this article).

\begin{tabular}{|c|c|c|c|c|}
\hline Group & Tracer name (CAS RN) & Detection limit & General problems & Specific problems \\
\hline \multirow{8}{*}{ 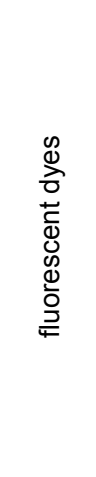 } & Uranine $^{*}(518-47-8)$ & $10^{-3} \mu \mathrm{g} / \mathrm{L}$ & \multirow{4}{*}{$\begin{array}{l}\text { Sensitive to light and } \\
\text { strong oxidants. }\end{array}$} & - \\
\hline & $\operatorname{Eosin}^{*}(17372-87-1)$ & \multirow{5}{*}{$10^{-2} \mu \mathrm{g} / \mathrm{L}$} & & - \\
\hline & Amidorhodamine $\mathrm{G}^{*}(5873-16-5)$ & & & - \\
\hline & Sulforhodamine B (3520-42-1) & & & Ecotoxicological concerns \\
\hline & Rhodamine WT (37299-86-8) & & \multirow{4}{*}{$\begin{array}{l}\text { Analytical interferences } \\
\text { between fluorescent dyes } \\
\text { of similar optical properties. }\end{array}$} & Genotoxic \\
\hline & Pyranine $^{*}(6358-69-6)$ & & & Biodegradable \\
\hline & 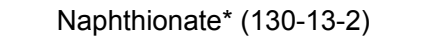 & \multirow{2}{*}{$10^{-1} \mu \mathrm{g} / \mathrm{L}$} & & Analytical (optical) \\
\hline & Tinopal CBS-X* (27344-41-8) & & & interference with DOC \\
\hline \multirow{7}{*}{$\frac{\infty}{\underset{\infty}{\varpi}}$} & Sodium & \multirow{4}{*}{$\begin{array}{l}\text { with ICP-MS } \\
\text { (only cations) } \\
10^{-3}-0.1 \mu \mathrm{g} / \mathrm{L}\end{array}$} & \multirow{3}{*}{$\begin{array}{l}\text { Sorption of cations } \\
(\mathrm{Sr}>\mathrm{K}>\mathrm{Na}>\mathrm{Li})\end{array}$} & - \\
\hline & Potassium & & & - \\
\hline & Lithium & & & - \\
\hline & Strontium & & \multirow{4}{*}{$\begin{array}{l}\text { Variable and sometimes } \\
\text { high natural background, } \\
\text { particularly for } \mathrm{Na} \text { and } \mathrm{Cl} \text {. }\end{array}$} & - \\
\hline & Chloride & \multirow{3}{*}{$\begin{array}{c}\text { with IC } \\
\text { (cations and } \\
0.1 \mathrm{mg} / \mathrm{L}\end{array}$} & & - \\
\hline & Bromide & & & Can form toxic compounds \\
\hline & lodide & & & Bio-chemically unstable \\
\hline \multirow{3}{*}{$\frac{\mathscr{O}}{\frac{\mathscr{U}}{0}}$} & Fluorescent microspheres* & \multirow{3}{*}{$\begin{array}{l}\text { Detection } \\
\text { of single } \\
\text { particles }\end{array}$} & \multirow{3}{*}{$\begin{array}{l}\text { Analysis is relatively } \\
\text { time consuming. } \\
\text { Prone to filtration. }\end{array}$} & - \\
\hline & Bacteria & & & Limited stability (inactivation) \\
\hline & Bacteriophages & & & Analysis within $24 \mathrm{~h}$ \\
\hline
\end{tabular}

Table 1: Summary of artificial tracers. Tracers classified as toxicologically "safe" by Behrens et al. (2001) are marked with an asterisk; the others were either not assessed or there are toxicological concerns. Chemical Abstracts Service Registry Numbers (CAS RN) allow unambiguous identification. DOC: dissolved organic carbon, ICP-MS: inductively coupled plasma - mass spectrometry, IC: ion chromatography. 
Salts are also often used as tracers. They dissolve in water into cations and anions, increasing the electrical conductivity (EC). Both cations and anions can be used as tracers, while measuring the EC provides a simple but less sensitive way of monitoring. $\mathrm{NaCl}$ is a cheap and commonly used tracer, mainly over short distances when high concentrations allow easy monitoring of EC. More specific chemical analysis allows use of lithium, potassium and strontium as cationic tracers, while bromide and iodide can be used as anionic tracers. Anions are generally more conservative than cations, which are prone to cation exchange and, thus, retardation. Variable natural background concentrations limit the use of salt tracers, and high concentrations may be harmful to biota.

Clubmoss (Lycopodium clavatum) spores were used as particulate tracers in the 1950s and 60s (Zötl, 1961). They have been superceded by fluorescent polystyrene microspheres that have precise diameters (0.05-90 $\mu \mathrm{m})$, physicochemical characteristics and optical properties, allowing various tracing options (Auckenthaler et al., 2002; Göppert \& Goldscheider, 2008). Lanthanide-labelled clay has also been used as a particulate tracer in karst (Mahler et al., 1998). Microbiological water tracers include bacteriophages (i.e. viruses that attack specific bacteria but are safe for humans and the environment) and bacteria (Harvey, 1997) (Table 1).

\section{Selection of tracers types and injection quantities}

The selection of the tracer depends on environmental impact (Behrens et al., 2001), cost and detectability. In a karst aquifer, uranine is often the first choice. For multi-tracer tests, it is therefore used at the remotest and/or most important injection site. However, there are a few constraints. Uranine is readily visible at concentrations exceeding $\sim 15 \mu \mathrm{g} / \mathrm{L}$, is sensitive to light and (because it is widely used as a colouring agent) may be present in the environment. Supplementary tracers are commonly selected based on their ease of analysis. Dyes that fluoresce at markedly shorter wavelengths (naphthionate or tinopal) or higher wavelengths (rhodamines) can be distinguished from uranine, while the simultaneous use of eosin and uranine requires more sophisticated analyses. Naphthionate or tinopal are recommended when visible colouring must be avoided, e.g. in the catchment of mineral springs (Goldscheider et al., 2003). However, where there is abundant dissolved organic carbon (DOC) in the water, the similarity in fluorescence wavelengths causes analytical interference.

Salts are a good choice for short traces and when visible colouring must be avoided. $\mathrm{NaCl}$ is particularly useful for small-scale tracer tests and for discharge measurements (salt-dilution method) where results can be generated immediately using an EC meter (Käss, 1998). However, much higher injection quantities are required than for fluorescent dyes, so longer traces require substantial injections that may result in unacceptably high concentrations. For multi-tracer tests, salts are often used together with fluorescent dyes, but for the closest and/or least important injection sites.

Particulate tracers are useful for investigations into the transport and attenuation of particlebound contaminants and microbial pathogens. However, particulate tracers can also be useful for conventional karst hydrogeological and speleological studies, because they are invisible in the water and show no analytical interferences with other tracers. Bacteriophages can be produced in huge quantities $\left(\sim 10^{15}\right.$ in $\left.10 \mathrm{~L}\right)$ but are detected at extremely low levels ( 1 phage / $2 \mathrm{~mL}$ ), which makes them favourable tracers when high dilution is expected (Goldscheider et al., 2007; Rossi et al., 1998). On the other hand, particulate tracers generally require more experience and specific laboratory equipment than conventional solute tracers.

The amount of tracer required depends on the properties of the tracer and the anticipated flow type. Field (2003) reviewed 33 tracer mass estimation equations, most of which are based on experience. A commonly used and very simple equation has been proposed by Käss (1998):

$\mathrm{M}=\mathrm{L} \cdot \mathrm{k} \cdot \mathrm{B}$

where $\mathrm{M}$ : tracer quantity, i.e. mass $[\mathrm{kg}$ ] or number of particles; L: distance $[\mathrm{km}]$, $\mathrm{k}$ : coefficient for tracer (uranine: 1, other fluorescence dyes: 2-15, salts: 1,000-20,000, particles: $\left.10^{12}-10^{13}\right) ; \mathrm{B}=$ factor for hydrogeological conditions (0.1-0.9 for karst aquifers). Worthington \& Smart (2003) suggest a more adaptable formula for karst tracing that includes system discharge $\mathrm{Q}[\mathrm{L} / \mathrm{s}]$ and target peak concentration $\mathrm{C}$ $[\mu \mathrm{g} / \mathrm{L}]$ :

$\mathrm{M}=1.9 \times 10^{-5}(\mathrm{LQ} \mathrm{C})^{0.95}$

Field (2002a) proposed a more quantitative "efficient hydrologic tracer-test design methodology" (EHTD) for the estimation of tracer injection masses and sampling frequencies, based on the one-dimensional advection dispersion equation (see section on evaluation and interpretation techniques further below). In any case, the user must weigh the risk of using excess dye against the consequences of failing to detect the tracer.

\section{Operation of tracer tests - from injection to monitoring}

Tracing involves large masses of tracer and very precise analysis, a situation that makes contamination a major risk. Great care must therefore be taken to separate tracer preparation and injection from sampling and analyses. Dry fluorescent dye powder is most risky as it can drift in air. Therefore, tracers are best dissolved prior to injection.

The selection of injection sites depends on the objectives of the investigation. Swallow holes or cave streams are generally the preferred choice as they carry the tracer directly into the active conduits. If naturally flowing water is not available, a large volume (usually several $\mathrm{m}^{3}$ ) of flushing water is needed, e.g. via tank trucks (Fig. 1). Tracers are normally injected instantaneously. However, the injection should not 
significantly increase the natural flow rate in order to avoid loss into adjacent rock volumes or on adjacent surfaces. This requires some compromise between distortion by flushing and duration of injection.

Sampling is best undertaken not only at the most likely downstream sites such as springs or cave streams, but also at possible and unlikely sites. This increases the chance of successful detection should preconceptions be incorrect and authenticates positive traces by the lack of contamination implied by negative results. There are three fundamentally different sampling methods, in the order of increasing sophistication (Benischke et al., 2007):

Integrative sampling means accumulation of tracer over a certain time, e.g. the adsorption of fluorescent dyes on granular activated charcoal, followed by elution and analysis in the laboratory (Käss, 1998). The method is relatively simple and provides continuous monitoring during the period of deployment. However, the concentration in the eluate can only crudely be translated into concentrations in the water, and the time resolution is only as good as the replacement rate of detectors. Charcoal bags are valuable in preliminary tests where travel time is unknown, for inaccessible sites (e.g. deep into difficult caves), as backup for other sampling methods, or where there are numerous monitoring sites.

Discrete sampling involves taking water samples at given points in time (manually or with an automatic sampler, Fig. 2) and analysing them in a laboratory, which results in a more or less detailed concentrationtime data series. Water samples can be analysed for all artificial tracers and natural water constituents; control and replicate analyses are possible.

Continuous monitoring delivers concentration-time data at extremely high temporal resolution (seconds to minutes). Modern submersible fluorimeters allow continuous monitoring of up to three fluorescent dyes (e.g. tinopal, uranine and a rhodamine dye), turbidity and temperature (Schnegg, 2002; Fig. 3); alternatively, the tinopal channel can also be used for the monitoring of organic carbon.

The first method is often referred to as "qualitative" tracing, while the other methods provide "quantitative" results. Integrative sampling is logistically simpler and is often used for tracer tests directed at establishing connection between two points, or where travel time and trajectories are completely unknown. However, detailed concentration-time data series prove that the tracer appeared in a coherent manner ruling out contamination or background variation. In many cases, different sampling methods can be combined, e.g., charcoal bags at less important or inaccessible sites and an automatic sampler at the more important, accessible sampling sites.

Blank samples should be collected before the tracer test to establish background concentrations. In order to record the complete tracer breakthrough at sufficient detail, sampling should start before or at the moment of tracer injection; intervals should be short at the beginning and then get successively longer; and sampling should last substantially longer than the

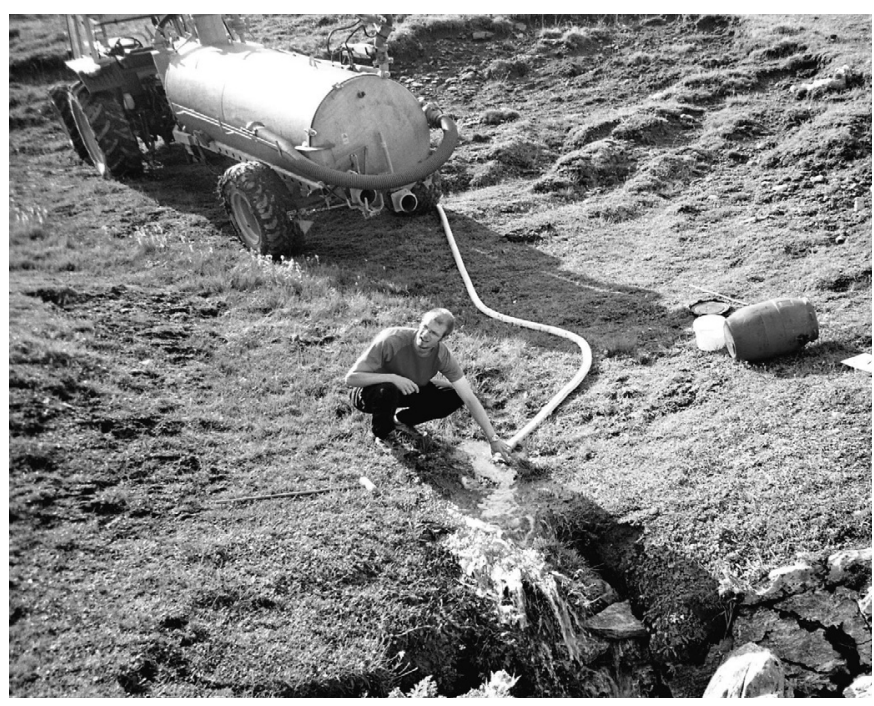

Fig. 1. Introduction of flushing water from a tank truck during and after the injection of a salt tracer into a shaft, Tsanfleuron glacier and karst aquifer system, Swiss Alps (photo: N. Goldscheider).

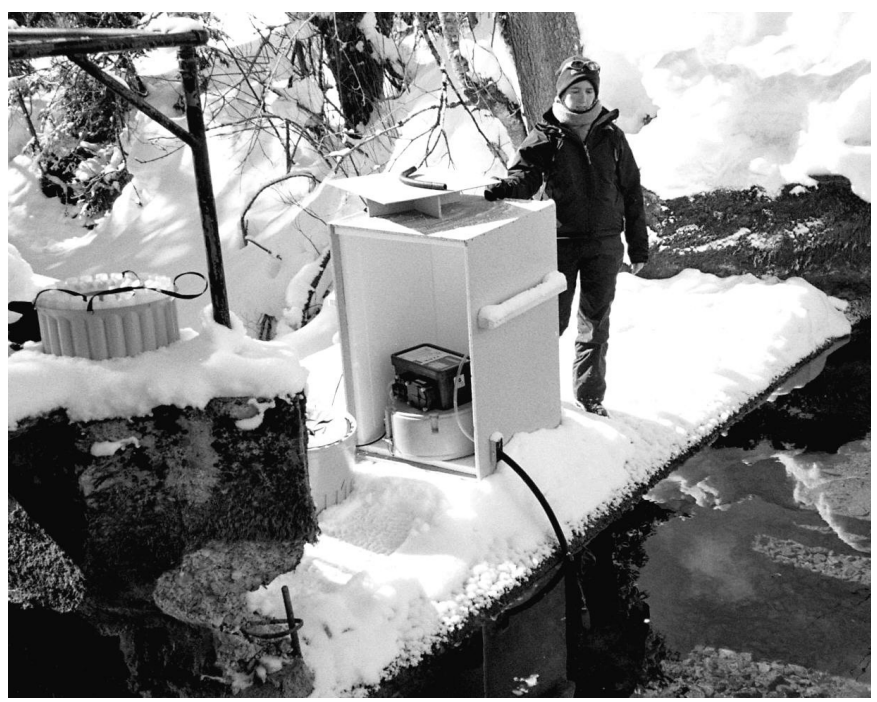

Fig. 2. Automatic sampler at the karst spring that drains the Hölloch cave in the Austro-German Alps (photo: N. Goldscheider). Due to temperatures down to $-20^{\circ} \mathrm{C}$, the sampler was placed into a heated insulated box.

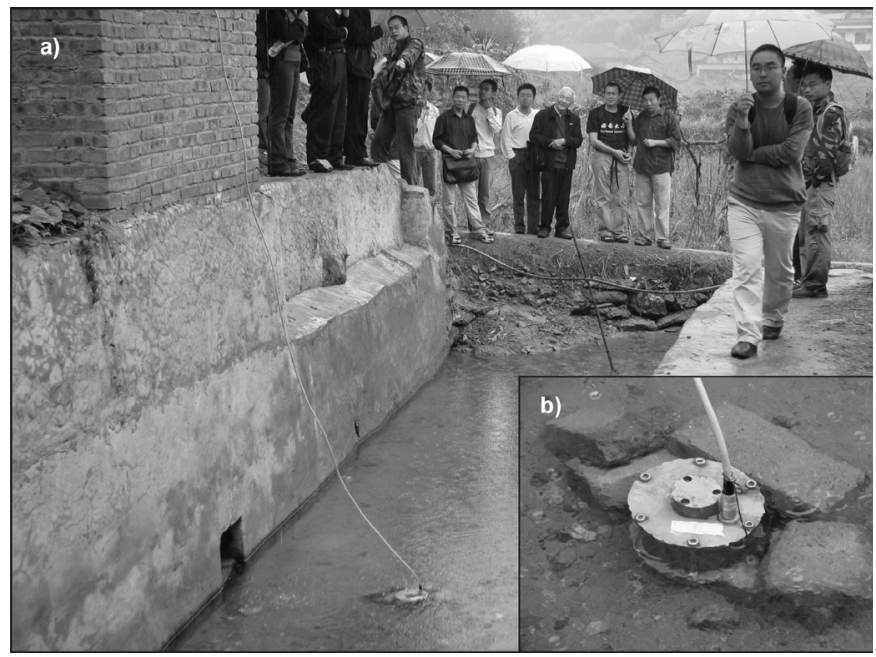

Fig. 3. a) Installation of a submersible flow-through field fluorimeter (GGUN-FL30; Schnegg, 2002) for continuous monitoring of fluorescent tracer concentrations at a karst spring in the Qing Muguan catchment, Chongqing province, China; b) detail of the instrument (photos: N. Goldscheider) 
time of maximum tracer concentration. Estimations of minimum and maximum flow velocities help to set up an appropriate sampling strategy. Sample analysis concurrent with the experiment make it possible to modify and optimise the sampling strategy during the experiment.

Spectrofluorimetry is the standard method of analysing fluorescent dyes in the laboratory. Detailed synchronous-scan spectra allow a better separation of fluorescence signals and the analytical background, and of different fluorescent dyes with similar optical properties. Furthermore, it is possible to enhance or reduce the fluorescence signal from a mix of dyes by modifying the chemistry of the water sample, e.g. acid buffers suppress the uranine signal, basic buffers reinforce it. Details concerning spectrofluorimetry, as well as analytical methods for salts and particulate tracers are described elsewhere (Käss, 1998).

\section{Basic evaluation and interpretation techniques}

The primary result of a quantitative tracer test is a breakthrough curve (BTC), i.e. a discrete or continuous series of concentration-time data (Fig. 4). The time axis is best expressed as time since tracer injection. BTCs allow considerable insight into the nature of the aquifer, groundwater flow, contaminant transport and the conduit network, especially if continuous discharge data (hydrographs) are additionally available.

For the comparison of different BTCs obtained from multi-tracer tests, it is often useful to divide all concentrations (c) by the respective input quantities (M). Such normalised concentrations (c/M) even make it possible to compare solute and particulate tracer BTCs.

The tracer recovery $\left(\mathrm{M}_{\mathrm{R}}\right)$ is the quantity of the injected tracer that arrived at a sampling site, expressed as an absolute (mass) or relative quantity (percentage of the injected mass). It is particularly useful for assessing the reliability of a trace and in the resolution of underground conduit networks, as will be shown in the next section. Recovery requires a quantitative BTC and concurrent discharge data. For constant discharge, the absolute recovery is the product of the area below the BTC and the discharge. For variable discharge, all tracer concentrations need to be multiplied with the corresponding discharge values in order to obtain fluxes (e.g. g/s), and the recovery is the area below this flux curve. The general formula is:

$$
M_{R}=\int_{t=0}^{\infty}(Q \cdot c) d t
$$

where $Q$ is discharge, $\mathrm{c}$ is concentration, and $(\mathrm{Q} \cdot \mathrm{c})$ is flux. In practice, the recovery is calculated by numerical integration in a suitable spreadsheet, i.e. by determining the area below the flux curve by subdividing the curve into columns (width = sampling interval) and summing.

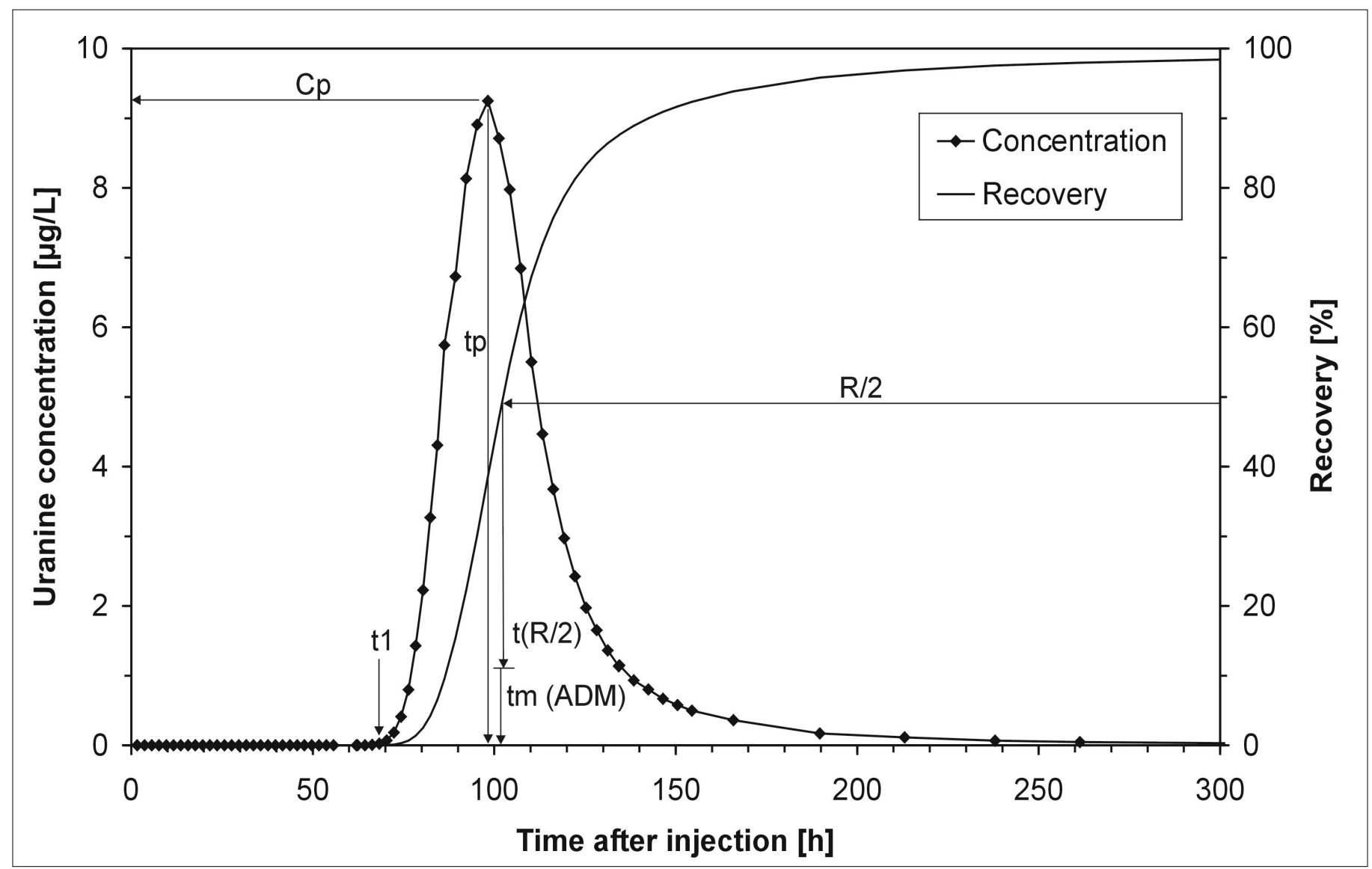

Fig. 4. Example of a tracer breakthrough curve $(B T C)$ and its basic features: $t 1=$ time of first arrival, $t p=$ peak time, $C p=p e a k$ (or maximum) concentration, $t(R / 2)=$ time when half of the recovered tracer has passed the sampling site, $t m(A D M)=$ mean transit time obtained from AdvectionDispersion Model. The data were obtained from the automatic sampler shown in Fig. 2 (Göppert \& Goldscheider, 2008). 
BTCs make it possible to determine transit times, which can be transformed into flow velocities if an appropriate flowpath length is known. The linear distance between injection and detection points provides a simple minimum but robust estimate, while information about the actual flowpath (e.g. in caves streams) allows more realistic, faster velocity estimations. The time of first tracer detection yields an estimate of the maximum flow velocity but depends on the analytical detection limit; the lower the detection limit, the earlier the first possible detection. The time of maximum concentration (or peak time) yields the dominant or peak velocity and is the most readily determined. The time of the concentration centroid or the time when half of the recovered tracer has passed the sampling site provide good approximations to the mean transit time, which can best be obtained by analytical modelling (see below).

Water and tracers do not flow at one single advective velocity but experience a wide range of velocities, from rapid flow in the centres of large conduits to slow flow in adjacent voids. This variance of velocities is referred to as dispersion and is reflected in the width of the BTC. Tracer transport can be described mathematically by the advection-dispersion equation (Bear, 1979). Analytical solutions are available for different initial and boundary conditions and are referred to as advection-dispersion models (ADM). In order to obtain quantitative transport parameters, the model is fitted to the measured data by varying the parameters until a best-fit is achieved. Although most analytical models have been developed for porous media, they are often applied to karst, but the results must be considered with care. In conduits, dispersion is most significant in flow direction, so that onedimensional (1D) models can be used, such as the ADM proposed by Kreft \& Zuber (1978).

BTCs from karst tracer tests sometimes show multiple peaks (see example from Mammoth Cave below). A possible explanation is multiple flowpaths, in which case a multi-dispersion model (MDM) can be applied, i.e. superposition of several ADMs (Maloszewski et al., 1992). However, retention of tracer and remobilisation can also lead to multiple peaks, normally associated with a runoff event. A replicate trace under steady flow can resolve which model is appropriate. BTCs from tracer tests in karst often show a significant tail that can result from retention of tracer in "dead zones" such as pools, or from adsorption-desorption of the tracer. Field \& Pinsky (2000) proposed an analytical model that represents non-equilibrium exchange between mobile and immobile fluid regions in karst conduits.

Different free software tools are available for the analysis of tracer BTCs, such as TRACI (Werner, 1998) (with MDM options) and CXTFIT (Toride et al., 1999), the most commonly used and most flexible code for the main types of transport processes.

QTRACER2 is an easy-to-use computer program for the analysis of tracer tests from karst and other hydrological settings. It delivers tracer recovery, transit times, dispersion, conduit cross-sectional area and volume, and other type of interpretations (Field, 2002b).

\section{TRACER TESTS AS TOOLS FOR SPELEOLOGY}

\section{Point-to-point tracing in caves}

Speleologists are concerned with caves, their form, history and function, and generally view the cave system as emplaced in an impassive medium rather than conduits in an aquifer. Water tracing can only be used in hydrologically active caves and is usually focussed on identifying and characterising unidentified caves, particularly in revealing underground connections. The primary questions are therefore concerned with connectivity, typically between a sinking stream or cave siphon and springs or cave streams.

Speleological tracer technique is often rather simple, because the questions may initially concern basic issues of connectivity, and underground work is often logistically challenging. Particular care is needed to avoid contamination, through burst dye containers, crawling in dyed water, or failing to seal samples adequately. Underground manual or auto sampling are difficult to coordinate when travel times and destinations are unknown and communications difficult, so the majority of cave traces use visible coloration or install charcoal detectors to establish local and longer links, respectively. The limitations of such "qualitative" sampling have been discussed above; whenever possible, more quantitative monitoring techniques should be applied. While it is tempting to trace a single linkage, much more information can be gained from systematic monitoring at intermediate points and alternative outlets. Broad sampling not only provides control, but often reveals unexpected connections.

By systematic monitoring and tracing, elementary linkages can be aggregated to define a cave stream network. A stream network is usually dendritic (tree like) with small streams congregating into a master conduit; many injection points often lead to few detection points. However, flow divergence can also be observed in karst aquifer systems. Where cave stream outlets have been buried by sediments, there is also often a distributary system where dye emerges at a number of springs. Where links are not proven, a hydrological divide can be inferred. However, negative results can also occur due to insufficient injection quantities or inappropriate monitoring. Therefore, the hydrological divide of a spring can only be reliably defined on the basis of positive traces that go to some other location.

Tracing linkages requires only binary results: positive or negative, and ideally these are clear cut. However, often there are indeterminate results that may arise from contamination, background or a weak signal. Whether these are an artefact of poor technique or real can be difficult to decide and this may require additional tracing to be resolved. Unfortunately, replicate cave tracing often yields inconsistent results, partly because of the simple methods used, but also 
because cave streams can be redirected under different flow conditions and as openings enlarge and constrict through sediment redistribution. Unlike surface stream networks which are almost universally dendritic, cave streams can split, rejoin and vary as passages flood and drain. The variability in results of replicate traces is therefore best regarded as a tool to reveal these important characteristics, rather than a confounding of a simple question. It also emphasises that karst catchments are not fixed with absolute boundaries

\section{Cave form from time of travel}

Interpretation of the form of cave passages requires higher order data, and more sophisticated sampling. Speleologists are particularly interested in whether a cave is air or water filled: vadose or phreatic. A simple (but imperfect) principle is that there is a greater volume in a phreatic passage, so it takes longer for a tracer to pass through. Tracer travel time can be obtained by sequential sampling or continuous monitoring. There is no absolute threshold velocity, so this method needs local knowledge and a sceptical approach.

A more substantial indicator of cave form is provided by "system volume". This is a descriptive statistic based on the volume of water displaced in the conduit during the duration of the trace. Formally, the "system volume" (V) is the integral of discharge (Q) from injection time $(\mathrm{t}=0)$ to mean transit time $(\mathrm{tm})$ :

$$
V=\int_{t=0}^{m} Q d t
$$

Discharge requires additional field work, although it can be minimised by using an established gauging station (if you are lucky), or by running under steady flow such as during a sustained recession (in which case a single discharge estimate is needed and simply multiplied by the tracer travel time to get system volume). System volume is generally larger for phreatic caves.

The concept of system volume is based on a single uniform conduit, while more realistic caves may be poorly represented (Fig. 5). Nevertheless, extending the idea to an "equivalent" cylindrical conduit can guide the imagination. Thus the volume to be divided by distance to get cross sectional area, and thus conduit radius (e.g. Smart, $1988 b)$. System volume generally increases with flow, with the volume-discharge relationship defining the hydraulic form of the cave system. The zero discharge intercept of the relationship is known as "static" storage. This is the volume below the spring outlet elevation, presumably indicating the permanent phreatic volume of the cave.

The relationship between travel time and discharge in phreatic caves is linear because changes in flow are predominantly accommodated by adjustments in velocity. Vadose caves normally show a nonlinear relationship between travel time and discharge because increased flow is partly accommodated by increases in cross-sectional area (Stanton \& Smart, 1981). Similarly, vadose dye traces during a period of increasing flow are faster than during declining flow. Not only is this "hysteresis" characteristic of vadose caves, but the associated estimates of system volume provide an indication of the dynamic storage of the cave. Unfortunately, more complex cave systems may not show consistent travel time-discharge relations because the routing of tracer is sensitive to the different inflows and the resulting hydraulic head and hydraulic gradients that result. Stream sinks and rising phreatic conduits are also prone to choking and reopening with significant effects on tracer movement.

Flood waves travel down stream faster than the water. In vadose streams, a flood wave travels at about $1.3 \mathrm{x}$ the velocity of the water (depending on the cave form). Flood waves travel almost instantaneously through phreatic conduits (depending on the form of the cave at the siphon). Natural flood waves may be difficult to use, but more tractable artificial floods can be induced by dam releases (e.g. Williams, 1977). If the flood wave contains tracer, then the separation between the dye and the impulse indicates the nature of the intervening conduit. For example, any pulse delay can be attributed to vadose travel time. The associated tracer travel time will be slower by a factor of 1.3 . Total tracer travel time minus the vadose travel time gives the phreatic travel time. Respective vadose and phreatic volumes can then be computed using the system volume method over the appropriate time intervals. One of the few combined pulse and tracer experiment was reported by Smart \& Hodge (1980).

\section{Characterisation of conduit networks}

Greater resolution of karst conduit networks may be possible with fully configured tests where the injection tracer mass and input discharge can be compared to the recovered mass and output discharge. The rules for interpretation allow simple conduit networks to be deciphered (Fig. 5).

It becomes difficult to undertake such analysis in more complex systems where there are multiple

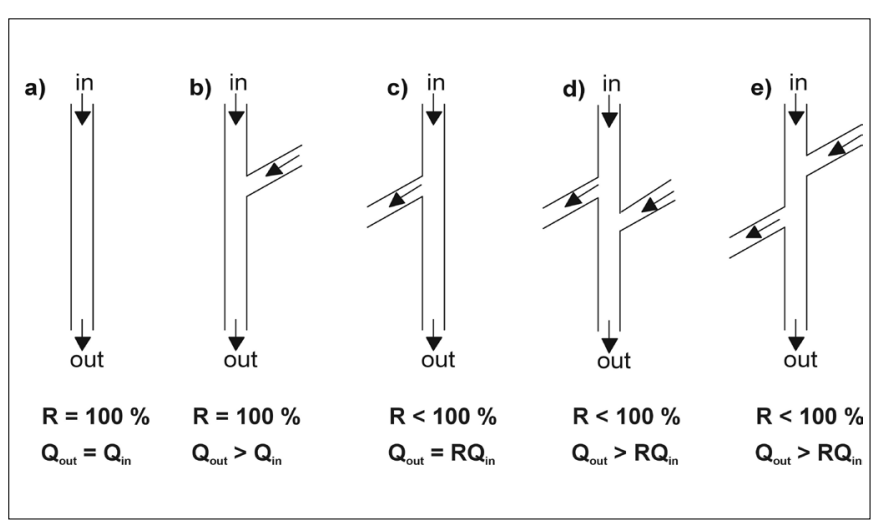

Fig. 5. Conduit network configurations based upon the measurement of input discharge $\left(Q_{\text {in }}\right)$, output discharge $\left(Q_{\text {out }}\right)$ and tracer recovery $(R)$ under steady flow conditions; $d$ and e can not be differentiated unless supplementary information is available, e.g. speleological observations. The complexity of real karst systems makes it difficult to resolve to clear configurations (after Brown \& Wigley, 1969; Smart, 1988a). 
outlets, particularly where discharge measurements may be difficult. From a speleological viewpoint, the key question is whether there are discrete caves feeding such outlets, for example where a rockfall or sediment has blocked a cave. The tracer concentration or form of the breakthrough curve from various outlets can be classified into similar groups that can have a spatial pattern indicative of internal drainage systems. Logistically, constructing multiple breakthrough curves may be difficult unless a real time monitoring system is in place to provide tactical direction for sampling. Otherwise, integrative sampling with activated charcoal may be the only way to generate any data.

Where circumstances permit both discharge and tracer breakthrough to be monitored, then each outlet in a pure distributary would show tracer recovery in direct proportion to the fraction of discharge emerging. The "dimensionless recovery index" $\left(D_{j}=R_{j} /\left(Q_{j} / Q_{T}\right)\right.$, where $j$ indicates each particular outlet and $Q_{T}$ is total discharge) will equal unity in this case. Systematic dilution will result in $D_{j}<1$, and relative enrichment $D_{j}>1$. The shift in $D_{j}$ with discharge can be used to diagnose system structure (Smart, 1988a).

Much cave exploration takes place in fossil conduits lacking streams. Tracing of such systems may reveal only later vadose invasion routes that are speleologically less interesting, or possibly indicate an unknown entrance. Even in hydrologically active conduits, artificial tracing alone is unlikely to reveal detailed conduit structures. The combination of artificial tracing and discharge measurements with natural tracers, such as temperature, chemical and isotopic data, can provide much more insight even into completely inaccessible deep phreatic conduit networks (e.g. Pronk et al., 2006).

\section{Conceptual model of an active flow conduit system, Mammoth Cave, USA}

The Buffalo Spring karst watershed at Mammoth Cave National Park, Kentucky, USA, consists of a surface drainage system that is partly and seasonally drained through karst (Ryan, 1992; Meiman \& Ryan, 1999). Buffalo Spring, issuing from the shallow phreatic with an average discharge of $\sim 500 \mathrm{~L} / \mathrm{s}$, is located at the mouth of Buffalo Creek at the Green River. The spring is stratigraphically situated in the middle of the Girkin Formation, a $25 \mathrm{~m}$ thick cavernous limestone forming the uppermost of the $>100 \mathrm{~m}$, nearly horizontally bedded limestone sequence comprising the Mammoth Cave Aquifer. The primary tributaries to Buffalo Creek, the Wet Prong and the Dry Prong (Fig. 6), are oriented roughly NE-SW, along the regional strike. Surface flow in the tributaries typically sinks into the Girkin Formation, which is exposed only along the floors of the Wet and Dry Prongs, just downstream from the contact of the overlying Big Clifty Sandstone. Point-to point tracing using charcoal detectors indicated that the recharge area for Buffalo Spring $\left(25 \mathrm{~km}^{2}\right)$ is nearly identical to the Buffalo Creek surface catchment. In order to obtain a better conceptual model of the active flow conduit network, nine quantitative traces were completed and up to three fluorometers were deployed at a given time, taking the advantage of multiple conduit access points.

The tracer dye Rhodamine WT (classified as "genotoxic" by Behrens et al. 2001 but still widely used in the US) was injected at the Wet Prong sinkpoint at the same time fluorescein (uranine) was injected into the cave stream of Fort's Funnel Cave (Fig. 6). The dye cloud from the Wet Prong arrived at the sampling site at Buffalo Spring ahead of the dye from the much closer Fort's Funnel. These results seemed to conflict with qualitative tracer tests, which had shown that water sinking in the Wet Prong passes through Fort's Funnel on its way to Buffalo Spring. From quantitative traces it became apparent that the Buffalo Spring basin includes two major trunk conduits -- the Wet Prong and the Dry Prong trunk (the latter accessible through Fort's Funnel and Buffalo Creek Cave). The two trunks join somewhere between Fort's Funnel and Buffalo Spring. A minor conduit or temporary overflow must pirate a small portion of flow from the Wet Prong trunk into the Dry Prong trunk upstream from Fort's Funnel, but the initial tracing method lacked the time resolution to distinguish these features. The greater tracer velocity through the Wet Prong conduit implies a smaller system volume relative to the discharge allowing the tracer through faster. Whether this indicates a steeper hydraulic gradient and lower flow resistance would require flood impulse tests to be investigated. The cross-link between the two conduits is shown as the "Piracy Route" in the pipe-diagram of Fig. 6. Further tests would be required to show whether it was an abandoned route functioning only during high flows, or a newly developing piracy of limited capacity carrying small flows at all times.

Double-peaked recovery curves were recorded at Fort's Funnel and Buffalo Spring during several traces from the Dry Prong sinkpoint (Fig. 7). There were no double-peaks recorded in Buffalo Creek Cave. The double-peaked curves suggest the presence of a bifurcated flow path. The absence of a doublepeaked curve at Buffalo Creek Cave implies that the bifurcation must be located between Buffalo Creek Cave and Fort's Funnel. This section of trunk is inaccessible due to terminal sumps in these caves.

It is possible to further infer the nature of the anastomosis through the interpretation of mapped passages of Buffalo Creek Cave. Mapping the stream passage of Buffalo Creek Cave revealed an abundance of similar flood cut-arounds ranging between 50 to 300 meters in length. During moderate to high flow they serve as auxiliary flow paths. The bifurcation responsible for the double dye peaks at Fort's Funnel may be a similar flood cut-around. This interpretation is supported by a series of repeated traces during falling discharge. The dual peaks eventually disappear and only one peak remains under lower flow conditions; one of the routes is apparently abandoned at some point during receding flow. 


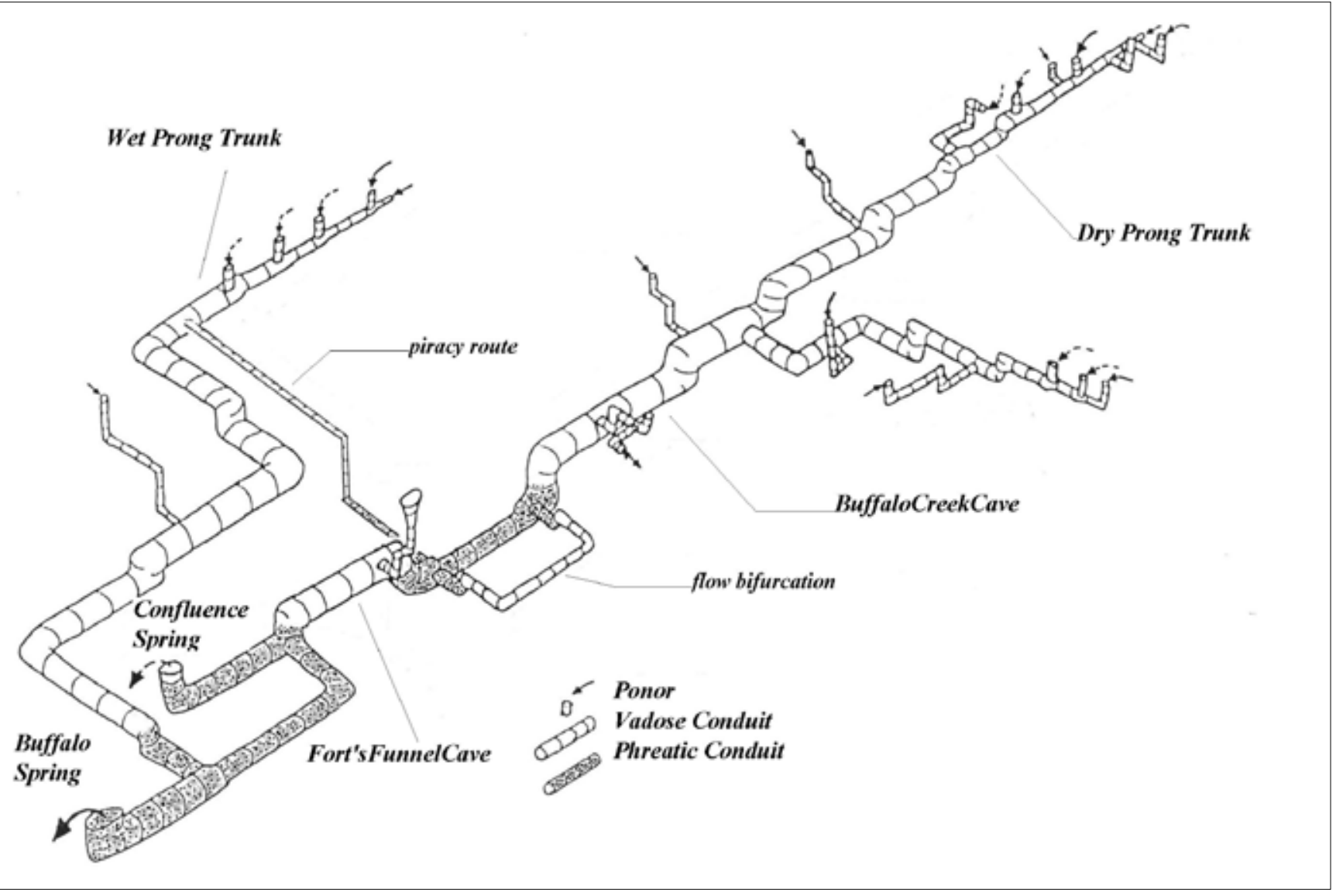

Fig. 6. Pipe Diagram of the Buffalo Spring groundwater basin active conduit flow system.

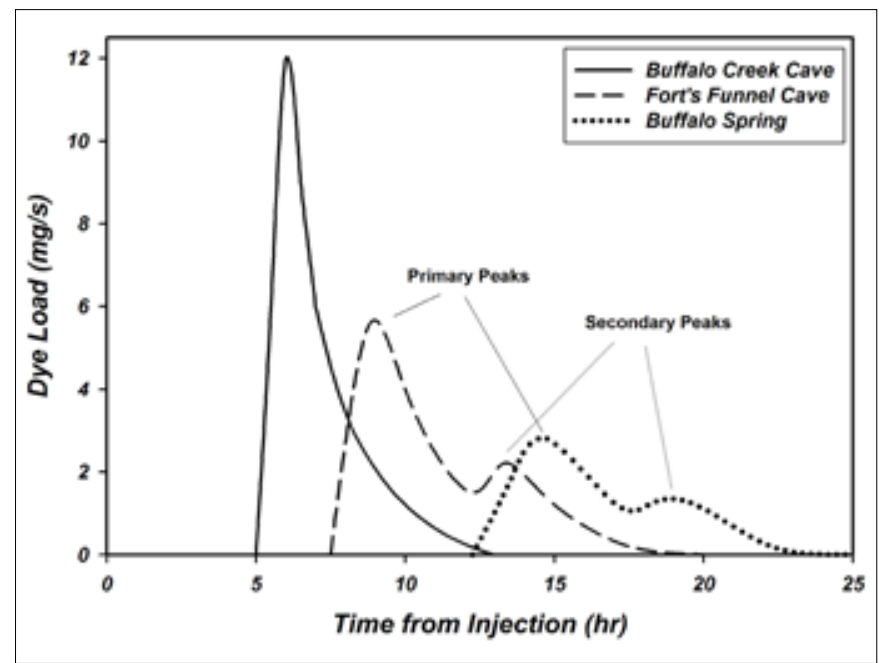

Fig. 7. Double-peaked recovery curves developing along a common conduit indicative of a flow bifurcation. Location of the sampling sites see Fig. 6.

\section{CAVES AS OBSERVATION AND EXPERIMENTAL SITES FOR TRACER TESTS}

\section{Generalities, objectives and methodological adaptations}

Caves offer the unique opportunity to access the karst aquifer and directly observe water percolation through the unsaturated zone and water flow in cave streams and conduits. The unsaturated zone can promote or ameliorate karst aquifer contamination and so there has been interest in how it affects aquifer vulnerability and protection (e.g. Aquilina et al.,
2006). To validate aquifer vulnerability assessments, Goldscheider et al. (2001) determined peak times, normalised maximum concentrations and recoveries for tracers released on the soil surface and detected at a karst spring. Perrin et al. (2004) further developed this approach by including monitoring sites inside caves and demonstrated considerable water storage and reactive processes in the unsaturated zone.

For this type of experiment, the tracers are spread at the land surface using a watering can or a garden sprinkler system, and flushed into the underground either by natural rainfall (which requires careful timing) or by artificial rainfall (which can require the provision of several $\mathrm{m}^{3}$ of water). Different techniques can be applied for the sampling and monitoring inside the cave, dependent on the type and quantity of water flow. Monitoring in cave streams can be done by means of manual or automatic sampling, or continuous monitoring. Cave drips can either be directly manually sampled, or via funnels or collectors consisting of plastic sheets, connected with automatic samplers or monitoring devices, such as field fluorimeters for continuous tracer detection (Fig. 8). Flow rates can be measured directly as captured volume per time interval, or indirectly through rated flow devices. Recoveries are often low for unsaturated zone traces, partly because the tracer is distributed amongst many flow routes, few of which may be sampled, and partly because of adsorption and retention in the soil and epikarst.

Qualitative tracing of discrete unsaturated zone 


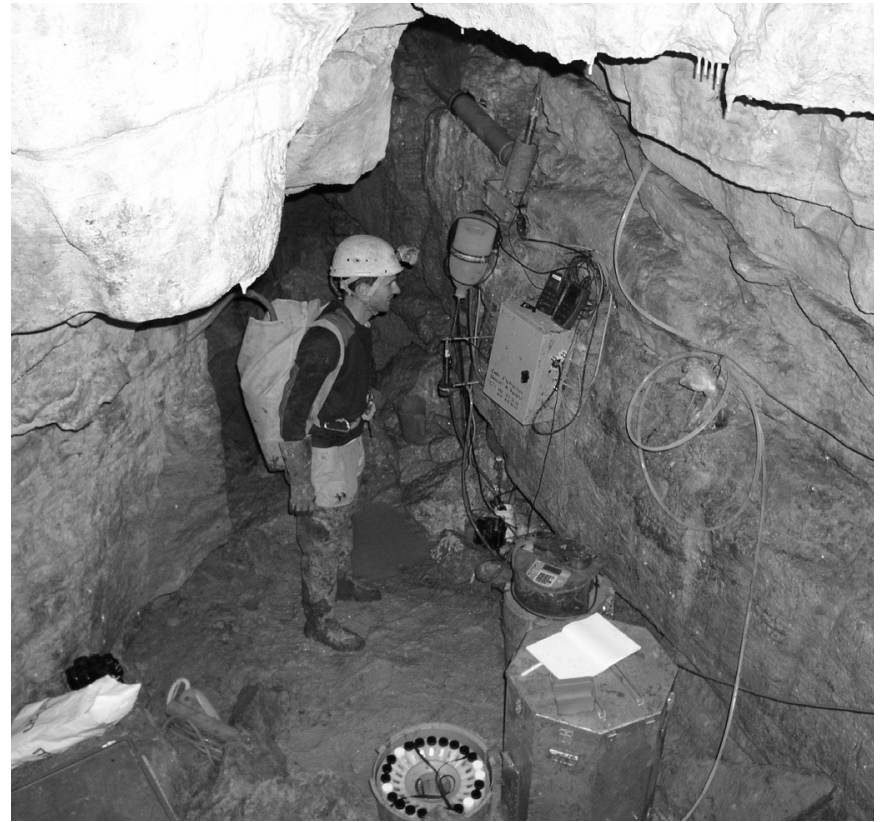

Fig. 8. Sampling and monitoring facilities for unsaturated zone investigations inside a small cave in the Swiss Jura Mountains, with cave drip-water collector, different probes, data logger and automatic sampler (photo: L. Savoy). A similar experimental set-up was used for the study from Switzerland described below.

\section{recharge, Mammoth Cave, USA}

The vadose, or unsaturated, zone of the Mammoth Cave karst aquifer extends down through $120 \mathrm{~m}$; from the contact of the Big Clifty Sandstone and the underlying Girkin Limestone down to the base level stream passages of the cave. While the aquifer is recharged in large part by the sinking streams and thousands of dolines of the Pennyroyal Plateau, the sandstone-limestone contact that traces the edge of the ridges of the Mammoth Cave Questa provides numerous points of concentrated allogenic recharge. Here, surface runoff enters the aquifer via stream sinkpoints that form a virtual curtain of vertical shafts in the cave below. While hundreds of vertical shafts have been discovered in Mammoth Cave, perhaps less than $10 \%$ of all existing shafts have been found.

During the spring of 2000, small quantities of fluorescein $(10 \mathrm{~g})$ and rhodamine WT $(25 \mathrm{~mL})$ were injected into the eastern and western sinkpoints of two contact streams sinking $50 \mathrm{~m}$ above the top of Edna's Dome shaft complex in Mammoth Cave (Talley et al. 2002, Merideth, MS thesis in preparation, Fig. 9). This site and three nearby shafts within $50 \mathrm{~m}$ - the Water Clock, Einbigler's Dome, and Nelson's

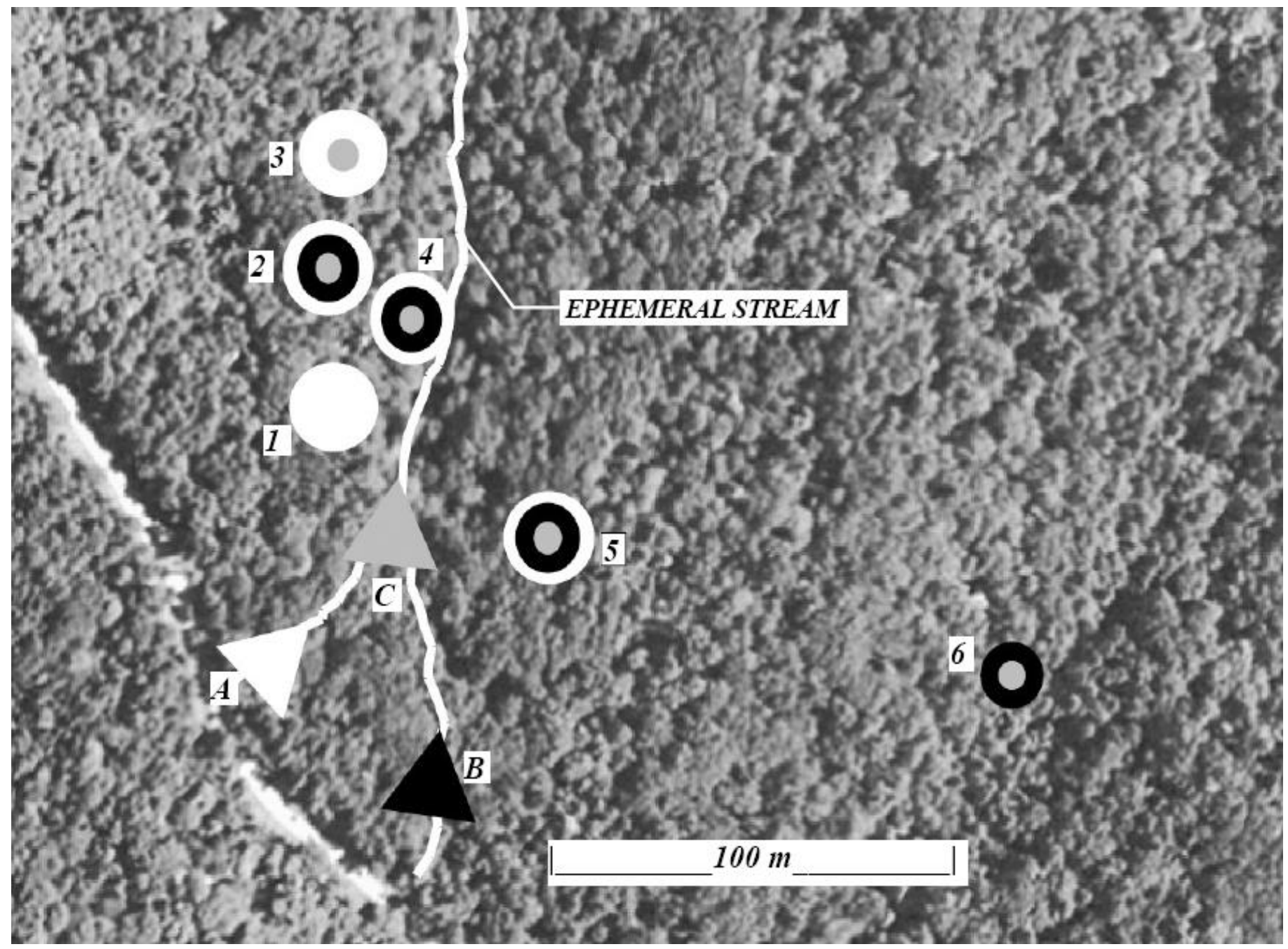

Fig. 9. Aerial view of dye trace study. Injection locations: (A) fluorescein, (B) rhodamine WT, (C) eosin Injections into surface streams. Underground sampling locations: (1) Edna's Dome, (2) Water Clock, (3) Nelson's Dome, (4) Einbigler's Dome, (5) Hawkin's Spring, (6) Cathedral Dome. The different greyscales symbolise the respective tracer injection and recovery sites. 
Dome - were also monitored with activated charcoal detectors. Two additional sites, Hawkin's Spring and Cathedral Domes ( 40 m high) were monitored. These sites are near the next intervening valley, $\sim 150$ $\mathrm{m}$ to the east.

There were two lessons learned by these simple qualitative traces (Merideth, 2007). First, the lateral connectivity, or dispersal, of the dye was interesting. The fluorescein was found within hours to days at five of the six shafts - the only exception being Cathedral Dome. Rhodamine WT was not found at any site during the initial trace, so after a few weeks, $300 \mathrm{~mL}$ of rhodamine WT was injected at the same sinkpoint. Apparently not enough dye was initially used as the larger injection produced positive results at five of the six sites, this time the exceptions being Edna's and Nelson's Domes - bypassing the apparently intervening Water Clock and Einbigler's Dome. A third injection soon followed when $15 \mathrm{~g}$ of eosin was injected into a sinkpoint at the confluence of the east and west branches. Eosin was found at all sites with the exception of Edna's Dome. Not only the complexity of the vadose zone apparent from this simple trace, but also that ponors only a few tens of meters apart can take water into vastly different flow trajectories.

As the top of these large vertical shafts are only a few tens of meters below the surface, one may reasonable conclude that a parcel of dye would make its way through in short order. Dye was recovered from these sites for over 180 days following injection. While the second rhodamine WT trace was perhaps a bit excessive, it was surprising that the small dose of fluorescein was detected for a half year later.

\section{Tracing of diffuse recharge of the unsaturated zone (Jura Mountains, Switzerland)}

Diffuse recharge from rainfall is expected to behave differently from discrete sinking streams. The Vers-chez-le-Brandt cave is located beneath flat pasture lands in the Jura Mountains of Northwest Switzerland. Approximately $2 \mathrm{~m}$ of soil/loess and
$30 \mathrm{~m}$ of unsaturated limestone overlie the $200 \mathrm{~m}$ long, near horizontal cave (Fig. 10). Ready access and uniform cover make this cave a suitable experimental site for unsaturated zone tracings. Recent experiments at this test site were aimed at improving understanding of water movement and the transport of solutes, colloids and particles. McCarthy $\&$ McKay (2004) note that most research on colloidal transport was done in porous media and at a lab scale, while more field experiments are required in karst aquifers, particularly in the unsaturated zone. The fact that microbial pathogens in water are often associated with suspended mineral particles (Mahler et al., 2000) illustrates the significance of such experiments.

A combined irrigation and tracing experiment was undertaken during a dry period in autumn 2005. An area of $28 \mathrm{~m}^{2}$ above the cave was irrigated for 13 hours using a garden sprinkler connected to a pump and a reservoir of $6000 \mathrm{~L}$. The pump rate was constant at about $450 \mathrm{~L} / \mathrm{h}$, corresponding to an artificial rainfall intensity of $16 \mathrm{~mm} / \mathrm{h}$. Water from several drip points in the cave was collected on plastic sheets and fed through a continuous flow gauge and a fluorimeter (GGUN-FL30, Schnegg, 2002) to provide a record of discharge, electrical conductivity, water temperature, total organic carbon (TOC), turbidity and uranine concentrations. After stable conditions were reached in the cave (i.e. steady discharge, stable and low level of turbidity), a pulse of uranine $(0.52 \mathrm{~g})$ and natural mud (3.6 L of clayey loam suspension) diluted in $40 \mathrm{~L}$ of water was sprayed on the land surface for seven minutes.

About 60 minutes after the injection, uranine concentration and turbidity started to increase simultaneously. The turbidity maximum occurred after 100 minutes, preceding the uranine maximum by about 25 minutes. About 6.5 hours after the injection, turbidity went down to the previous level, while the uranine BTC displayed a long tail. Uranine recovery reached $21.9 \%$,
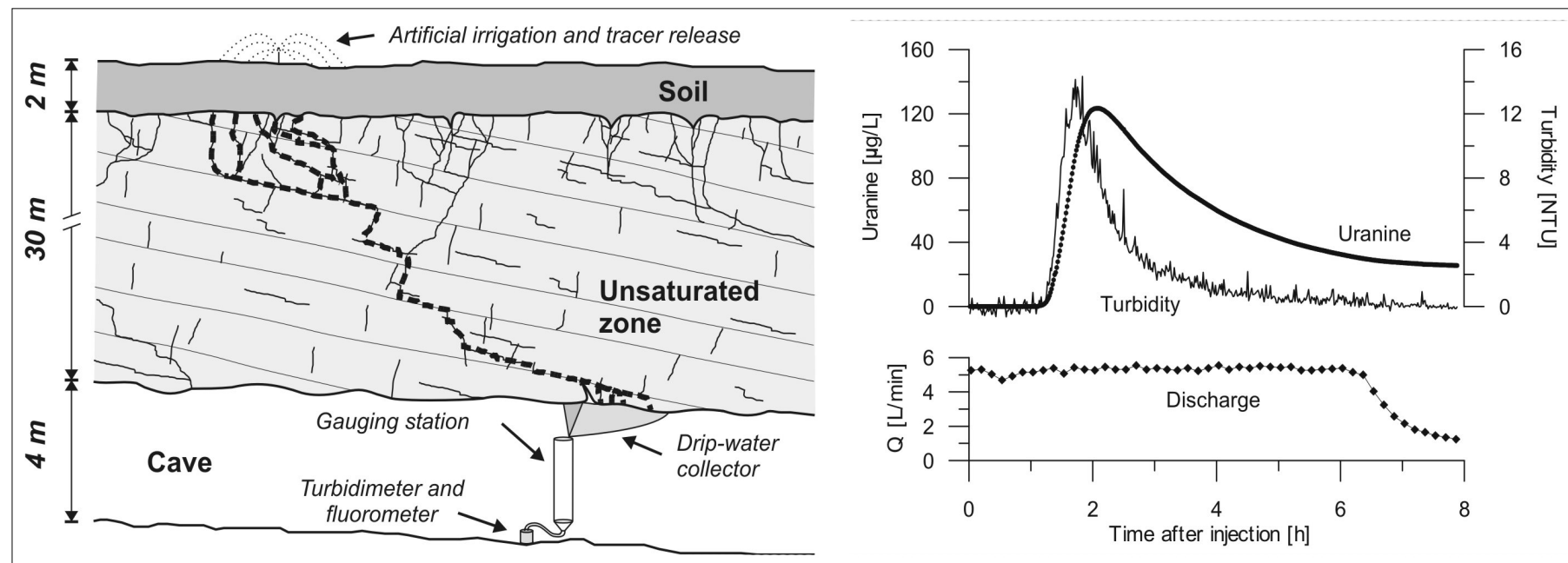

Fig. 10. Tracing experiment at the Vers-chez-le-Brandt cave experimental site. Left : Schematic cross-section. Right: Results of the comparative tracer test with uranine and natural mud (turbidity). 
while the recovery of the injected mud cannot be quantified precisely.

The results demonstrate an indirect, but discrete flow path between the surface and the unsaturated zone, with remarkably little retardation. The comparative evaluation of the BTCs give further insights into the transport of solutes and colloids/ particles in the unsaturated karst zone. Colloids were often reported to travel at higher mean velocities than solutes through porous media due to exclusion processes, i.e. preferential transport in the centres of the largest pores (Keller et al., 2004). Similar processes may operate in unsaturated carbonate rocks, although a time-dependent loss function may also explain the observed turbidity BTC.

\section{SUMMARY AND CONCLUSIONS}

Tracer tests can provide information on the inaccessible or as yet unexplored parts of cave and conduit networks. Caves can in turn be used as experimental and monitoring sites, allowing observation and sampling of the water in the unsaturated and saturated zone of a karst aquifer.

From a speleological perspective, most tracing focuses on the former problem, in particular determining the configuration and form of unexplored cave passage. Simple connectivity questions are often tackled using activated charcoal detectors. While such qualitative tracing may be a good option for reconnaissance studies with a large number of sampling sites that are difficult to access, it delivers limited information. Detailed concentration-discharge-time data (breakthrough curves) provide insights into the geometry and properties of underground conduit networks, as well as groundwater flow and contaminant transport in the aquifer. In the example from the Buffalo spring catchment, Mammoth Cave National Park, detailed breakthrough curves monitored at three sites inside a cave system made it possible to identify and characterise a flow bifurcation that becomes active during high flow conditions.

The protection of water resources in karst aquifers requires understanding of the transfer of water and contaminants through the soil, epikarst, unsaturated zone and active conduit network towards springs or other drinking water abstraction points. Caves provide access to the unsaturated zone and parts of the active conduit network, allowing direct assessment of recharge processes and contaminant transfer. The results from the unsaturated zone reported here show much more rapid recharge and transport than might be expected through soil and rock, indicating the presence of well-developed pathways. In the example of vadose zone recharge from Mammoth Cave, the tracing results indicate a complex and changing network of flow routes between ponors and caves hosting unsteady flow. The Jura example showed that not only water and solutes move though the unsaturated zone, but also suspended particles, which may act as vectors for microbial pathogens and chemical contaminants.

\section{REFERENCES}

Aquilina L., Ladouche B. \& Doerfliger N., 2006 - Water storage and transfer in the epikarst of karstic systems during high flow periods. Journal of Hydrology, 327(3-4): 472-485.

Auckenthaler A., Raso G. \& Huggenberger P., 2002 Particle transport in a karst aquifer: natural and artificial tracer experiments with bacteria, bacteriophages and microspheres. Water Science and Technology, 46(3): 131-138.

Bear J., 1979 - Hydraulics of Groundwater. McGraw-Hill, New York, 567 p.

Behrens H., Beims U., Dieter H., Dietze G., Eikmann T., Grummt T., Hanisch H., Henseling H., Käss W., Kerndorff H., Leibundgut C., Müller-Wegener U., Rönnefahrt I., Scharenberg B., Schleyer R., Schloz W. \& Tilkes F., 2001 - Toxicological and ecotoxicological assessment of water tracers. Hydrogeology Journal, 9(3): 321-325.

Benischke R., Goldscheider N. \& Smart C.C., 2007 - Tracer techniques. In: Goldscheider N. \& Drew D. (Eds.) - Methods in Karst Hydrogeology. International Contributions to Hydrogeology. Taylor \& Francis, London, UK: 147-170.

Boyer D.G. \& Pasquarell G.C., 1999 - Agricultural land use impacts on bacterial water quality in a karst groundwater aquifer. Journal of the American Water Resources Association, 35(2): 291-300.

Brown M.C. \& Wigley, T.M.L., 1969 - Water budget studies in karst aquifers. Journal of Hydrology, 9(1): 113-116.

Criss R., Davisson L., Surbeck H. \& Winston W., 2007 - Isotopic methods. In: Goldscheider N. \& Drew D. (Eds.) - Methods in Karst Hydrogeology. International Contributions to Hydrogeology. Taylor \& Francis, London, UK: 123-145.

Field M.S., 2002a - Efficient hydrologic tracer-test design for tracer-mass estimation and sample-collection frequency, 1. Method development. Environmental Geology, 42(7): 827-838.

Field M.S., 2002b - The QTRACER2 program for tracerbreakthrough curve analysis for tracer tests in karstic aquifers and other hydrologic systems. 600/R-02/001, US EPA, Washington D.C.

Field M.S., 2003 - A review of some tracer-test design equations for tracer-mass estimation and samplecollection frequency. Environmental Geology, 43(8): 867-881.

Field M.S. \& Pinsky P.F., 2000 - A two-region nonequilibrium model for solute transport in solution conduits in karstic aquifers. Journal of Contaminant Hydrology, 44: 329-351.

Geyer T., Birk S., Licha T., Liedl R. \& Sauter M., 2007 - Multitracer test approach to characterize reactive transport in karst aquifers. Ground Water, 45(1): 36-45.

Goldscheider N., 2005 - Fold structure and 
underground drainage pattern in the alpine karst system Hochifen-Gottesacker. Eclogae Geologicae Helvetiae, 98: 1-17.

Goldscheider N., Haller L., Poté J., Wildi W. \& Zopfi J., 2007 - Characterizing water circulation and contaminant transport in Lake Geneva using bacteriophage tracer experiments and limnological methods. Environmental Science \& Technology, 41: 5252-5258.

Goldscheider N., Hötzl H., Fries W. \& Jordan P., 2001 - Validation of a vulnerability map (EPIK) with tracer tests. 7 th Conf. on Limestone Hydrology and Fissured Media, Besançon: 167-170.

Goldscheider N., Hötzl H., Käss W. \& Ufrecht W., 2003 - Combined tracer tests in the karst aquifer of the artesian mineral springs of Stuttgart, Germany. Environmental Geology, 43(8): 922-929.

Göppert N. \& Goldscheider N., 2008 - Solute and colloid transport in karst conduits under low and high flow conditions. Ground Water, published online. DOI: 10.1111/j.1745-6584.2007.00373.x

Harvey R.W., 1997 - Microorganisms as tracers in groundwater injection and recovery experiments: a review. FEMS Microbiology Reviews, 20(3-4): 461-472.

Hunkeler D. \& Mudry J., 2007 - Hydrochemical tracers. In: Goldscheider N. \& Drew D. (Eds.) - Methods in Karst Hydrogeology. International Contributions to Hydrogeology. Taylor \& Francis, London, UK: 93121.

Jeannin P.Y., Groves C. \& Häuselmann P., 2007 - Speleological investigations. In: Goldscheider N. \& Drew D. (Eds.) - Methods in Karst Hydrogeology. International Contributions to Hydrogeology. Taylor \& Francis, London, UK: 25-44.

Käss W., 1998 - Tracing Technique in Geohydrology. Balkema, Rotterdam: 600 p.

Keller A.A., Sirivithayapakorn S. \& Chrysikopoulos C.V., 2004 - Early breakthrough of colloids and bacteriophage MS2 in a water-saturated sand column. Water Resources Research, 40(8): W08304

Kreft A. \& Zuber A., 1978 - Physical meaning of dispersion equation and its solution for different initial and boundary conditions. Chemical Engineering Science, 33(11): 1471-1480.

Mahler B.J., Bennett P.C. \& Zimmerman M., 1998 - Lanthanide-labeled clay: A new method for tracing sediment transport in karst. Ground Water, 36(5): 835-843.

Mahler B.J., Personne J.C., Lods G.F. \& Drogue C., 2000 - Transport of free and particulate-associated bacteria in karst. Journal of Hydrology, 238(3-4): 179-193.

Maloszewski P., Benischke R. \& Harum T., 1992 Mathematical modelling of tracer experiments in the karst of Lurbach-System. Beitr. z. Hydrogeologie, 43: $116-136$.

Massei N., Wang H.Q., Field M.S., Dupont J.P., Bakalowicz M. \& Rodet J., 2006 - Interpreting tracer breakthrough tailing in a conduit-dominated karstic aquifer. Hydrogeology Journal, 14(6): 849-858.

McCarthy J.F. \& McKay L.D., 2004 - Colloid transport in the subsurface: Past, present, and future challenges. Vadose Zone Journal, 3(2): 326-337.

Meiman J. \& Ryan M.T., 1999 - The development of basin-scale conceptual models of the activeflow conduit system: Karst Modeling. Karst Waters Institute Special Publication, 5: 203-212.

Merideth, J., 2007 - Vadose zone hydrology near the vicinity of Edna's Dome, Mammoth Cave, Kentucky. MS Thesis, in prep., Western Kentucky University, Bowling Green Kentucky.

Perrin J., Pochon A., Jeannin P.Y. \& Zwahlen F., 2004Vulnerability assessment in karstic areas: validation by field experiments. Environmental Geology, 46(2): 237-245.

Pronk M., Goldscheider N., ZopfiJ., 2006-Dynamics and interaction of organic carbon, turbidity and bacteria in a karst aquifer system. Hydrogeology Journal, 14(4): 473-484.

Rossi P., Doerfliger N., Kennedy K., Müller I. \& Aragno M., 1998 - Bacteriophages as surface and ground water tracers. Hydrology and Earth System Sciences, 2(1): 101-110.

Ryan M.T., 1992 - Using newly-developed quantitative dye tracing techniques to determine the karst hydrology of the Buffalo Spring Groundwater Basin of Mammoth Cave National Park, Kentucky: MS Thesis, Eastern Kentucky University, Richmond Kentucky: 123 p.

Schnegg P.A., 2002 - An inexpensive field fluorometer for hydrogeological tracer tests with three tracers and turbidity measurement, XXXII IAH and ALHSUD Congress Groundwater \& Human Development.

Smart C.C., 1988a-Artificial tracer techniques for the determination of the structure of conduit aquifers. Ground Water, 26(4): 445-453.

Smart, C.C., 1988b - Quantitative tracing of the Maligne karst system, Alberta, Canada. J. Hydrol., 98: 185-204.

Smart P.L. \& Hodge P., 1980 - Determination of the character of the Longwood sinks to Cheddar resurgence conduit, using an artificial pulse wave. Transactions of the British Cave Research Association, 7: 208-211.

Stanton W. I. \& Smart, P.L., 1981 - Repeated dye traces of underground streams ion the Mendip Hills, Somerset. Proc Univ. Bristol Speleol. Soc., 16: 47-58.

Talley N., Groves C.G. \& Meiman J., 2002 Unsaturated zone hydrology of the Edna's Dome Shaft Complex of the Mammoth Cave System, Kentucky. Proceedings, Geologic Society of America, Denver Colorado.

Toride N., Leij F.J. \& van Genuchten M.T., 1999 - The CXTFIT code for estimating transport parameters from laboratory or field tracer experiments. Research Report No. 137, US Salinity Laboratory, USDA, ARS, Riversied, CA.

Werner A., 1998-TRACI, an example for mathematical tracing-interpretation model. In: Käss W., (Ed.) - Tracing techniques in Geohydrology. Balkema, Rotterdam, Brookfield: 376-381.

Williams P.W., 1977 - Hydrogeology of the 
Waikoropupu Springs: a major tidal karst resurgence in NW Nelson. Journal of Hydrology, 35: 73-92.

Worthington S.R.H. \& Smart C.C., 2003 - Empirical equations for determining tracer mass for sink to spring tracer testing in karst. In: Beck B.F. (Ed.) - Sinkholes and the engineering and environmental impacts of karst: 287-295.

Zötl J., 1961 - Die Hydrographie des nordostalpinen Karstes. Steir. Beitr. z. Hydrogeol., 1960/61(2): 54-183.

\section{Relevant Internet Links:}

Information on fluorescent dyes and other chemical compounds and unambiguous identification by means of Chemical Abstracts Service Registry Numbers (CAS RN): http://chemfinder.cambridgesoft.com/

CXTFIT software tool for the analytical modelling of tracer test data (free download):

http://www.pc-progress.cz/Pg_Stanmod.htm

QTRACER2 software tool for the evaluation of tracer breakthrough curves (free download):

http://cfpub.epa.gov/ncea/cfm/recordisplay. cfm?deid $=54930$

TRACI software tool for the analytical modelling of tracer breakthrough curves from karst aquifers; includes multidispersion options (free download):

http://www.schweizerbart.de/samples/017000930/ 